\title{
An overview on hermeneutics method application to the Quran by Muslim thinkers
}

\author{
Nur Zainatul Nadra Zainol ${ }^{1 *}$, Latifah Abdul Majid², Mohd Faizulamri Md Saad ${ }^{3}$, \\ ${ }^{I}$ Department of Research, Publication \& Documentation, Institute of Ahl Sunnah wal Jamaah, University Tun Hussein Onn Malaysia \\ Parit Raja, Batu Pahat, Johor, Malaysial \\ ${ }^{I}$ Department of Islamic Studies, Center for general Studies and Co-curricular, University Tun Hussein Onn Malaysia, Parit Raja, Batu \\ Pahat, Johor, Malaysia. \\ ${ }^{2,3}$ Department of Quranic and Hadith Studies, Faculty of Islamic Studies, National University of Malaysia, Bangi, Selangor, Malaysia \\ *Corresponding author E-mail: nadra@uthm.edu.my
}

\begin{abstract}
Hermeneutics method was introduced by modern Islamic thinkers where they see the need to apply the methods of hermeneutics in the interpretation of the Quran. Among of the thinkers are Fazlur Rahman, Nasr Hamid Abu Zayd and Arkoun who applying hermeneutics. Thus it occur a debate among Muslim scholars. Hence, this study aims to analyse the methods introduced by these scholars which were emphasizing in hermeneutics aspects.In this paper, the method of content analysis conducted can gatherrelevant facts on hermeneutics methods that have been applied against the Quran by modern thinkers as well as collecting information in other forms of interpretation that have been conducted by these modern thinkers. The views of contemporary scholars onthe true interpretation of Quran was also identified to argue the opinions of the modern thinkers who justify the hermeneutics methods.this study shows those modern thinkers have used the theories of hermeneutics as literary criticism, history and semiotic study of the Quran. The use of the method has downgraded the Quran by equating the Quran as literary works. Reinterpretationof the verses of the Quran based on the current context has made the issue of fiqh change and become controversial and this is against the opinion of the majority of scholars.
\end{abstract}

Keywords: Modern Thinkers; Liberalism; Content Analysis; Controversy; Hermeneutics

\section{Introduction}

Transmission of hermeneutics into the world of Islam has long taken place. Hermeneutics method was introduced by modern Islamic thinkers who acquired education in the West where they see the need to apply the methods of hermeneutics in the interpretation of the Quran. According to Rippin (1), the majority of modern scholars argue that Muslims do not understand the message of the Quran due to their lack of knowledge. Thus, the movement has been made to make Quran as a guide and there is a tendency in the interpretation of the Quran to view the message behind its texts. This movement was created by Muslim scholars to apply the methods of modern interpretations of contemporary and biblical criticism to the Quran. Hermeneutics method has been incorporated into the interpretation of the Quran by modern Muslim thinkers because they think hermeneutics and exegesis have something in common. Acording to Esack (2) in his book entitled 'the Quran: Pluralism and Liberation' noted that in general, hermeneutics and historical interpretation of the Quran has a pattern of hermeneutics. Although hermeneutics existed only recently in the Muslim community, the pattern of hermeneutics has long been practiced. Therefore, he argued about the patterns found in the traditional hermeneutics of the Quran, such as:

i. Studies on asbab al-nuzul and nasikh mansukh;

ii. The difference between understanding the Quran and method interpreted by commentators since the emerging science of interpretation; iii. Categorization method in interpreting Quran by commentators such as interpretation of Ahl al-Sunnah, Shia and Mutazila. This division showed a wide range of flow and a specific social ideology in the field of interpretation. It was named as hermeneutics.

However, the opinions of Esack were just coincidence, because the method was originally hermeneutics of Bible interpretation method, which is also the holy book of the Christian community. In the process of interpreting the Quran, it is not limited to the study of asbab al-nuzul and nasikh mansukh, where even the interpretation of the Quran involves various sciences. It also involves a specific and systematic methodology. Hermeneutics is not only the interpretation, but a 'method of interpretation' and its own philosophy which isvastly different compared to the interpretation of the Quran. Among the Christian community, the use of hermeneutics in the interpretation of the Bible is something very common although it also provokes debates $(3,4)$.

\subsection{Philosophy of Hermeneutics}

In the Muslim community, there are some modern Muslim thinkers who rejected the method agreed by mufassir salafi. They introduced a contemporary interpretation method instead of the method of interpretation which has been introduced by the mufassir salafi (4). According to Rahman (5), contemporary interpretation method was created to not accept the text of the Quran literally but to look further than the literal expression. The main purpose of this method is to reveal the 'soul' or moral message of the Quran. Thus, contemporary interpretations of various methods 
such as method of contextual, social and historical-critical method, a method of hermeneutics, were created. The statement was supported by Ahmad Shukri Salleh (2007: 41) where he noted that hermeneutics belongs to a contemporary interpretation method. This contemporary interpretation method is a method that evolves in modern times. The modern thinkers apply the contemporary methods that do not undergo the rules that have been outlined by the previous commentators.

\subsection{Modern Muslim Thinkers}

The philosophy of hermeneutics that grew out of research on the Bible was adapted by some modern Islamic thinkers such as Mohammad Arkoun, Fazlur Rahman and Nasr Hamid Abu Zayd to be absorbed in the study of the Quran. Therefore, this study aims to analyse the methods introduced by these scholars which were emphasizing in hermeneutics aspects.

\section{Literature Review}

Hermeneutics is a method of interpretation used to interpret the Bible. The hermeneutical method was introduced to the Bible as a result of the problems arising in an attempt to understand the Bible as originally the Old Testament found in the Christian community was in the form of a symbol. In addition, there are differences in interpretation between the Old Testament and the New Testament and the church's supremacy on the Bible encouraging the emergence of Biblical criticism (biblical criticism) methods.

Hermeneutics undergoes a definition of refinement and is not only used for the interpretation of the Bible but has been applied to the field of philosophy and humanity. The hermeneutical method was introduced by western scholars including (6-8) and Friedrich Schleiermacher (1768-1834 AD), William Dilthey (18331911 AD), Emilio Betti (1890-1968 AD), Erick `D. Hirsch (1928) and Hans Georg-Gadamer (1900-1998). Meanwhile, the hermeneutic method has been applied to the Koran by Western orientalists such as $(9,10)$ Abraham Geiger $(1810-1874$ AD), Gustav Weil (1808-1889 AD), Theodore Noldeke (1836-1930 AD), Arthur Jeffry (1893-1959 AD ) and others.

\subsection{Definition of Hermeneutic}

The word 'hermeneutik' is derived from the Greek word 'hermeneuein' which means to interpret, the word it develops into 'hermeneia' which means interpretation and the word 'hermeneutes' which means interpreter. This word is often associated with one of the Greek gods of Hermes who is regarded as the messenger of deities to humans. Hermas is the messenger of the gods in the sky to bring a message to man in the name of Islam Hermes is often associated with the Prophet Idris AS but for the ancient Egyptian society, Hermes is known as Unukh and among the Persi Ancient community it is known as Hushang (11).

Among the terms 'hermeneutic' and 'hermeneutics' there is a difference that is the first term to be the adjective that when translated it can be interpreted as a character in one interpretation. According to Faiz (11) the second term refers to the noun and it contains three meanings namely:

i. Science of interpretation.

ii. Knowledge of the meaning contained in the words and expressions of the author.

iii. Interpretation that specifically shows the interpretation of the scriptures.

Etymologically, according to Bauman (12) hermeneutics defines as the ability to explain, exploring the message and the basic understanding of an obscure, rigid and contradictory speech or writing that creates confusion for listeners or readers.

Husaini (13) The term 'hermeneutics' comes from the Greek (ta Hermeneutik), the plural form of (to Hermeneutikon) which means things related to the understanding and translation of a message. Both of these words are absorbed from the words 'hermes' which according to the Greek people's beliefs are the gods sent by Zeus (God) to convey messages and news to people on earth. In Aristotle's logic work, the word 'hermeneias' means expression or statement only. While the New Encyclopedia Britannica (1985: 874) defines hermeneutics is a study of the general rules for interpreting the Bible, and based on the history of the primary purpose of hermeneutics and the methods of Jewish and Christian scholars is to unleash the truth and value of the Bible.

\subsection{Types of Hermeneutics}

Hermeneutical methodology derives from Greek tradition and later developed as a Biblical interpretation methodology. After being transformed, hermeneutics were not applied only to the Bible, but the hermeneutics were re-developed by theologians and philosophers as a general method of interpretation in the fields of social sciences and humanities (14). Hermeneutics undergoes developments and changes in terms of its use model which arise due to its diversity of definitions and hermeneutic understanding. According to Palmer (15) the chronological picture of the development of the definition and definition of the hermeneutik has been divided into six categories:

i. Hermeneutics as the theory of scripture interpretation

ii. Hermeneutik as a method of philology

iii. Hermeneutik as a linguistic understanding

iv. Hermeneutik as the basis of 'geisteswissenschaft'

v. Hermeneutik as phaseology of the casein

vi. Hermeneutik as a system of interpretation

\section{3 .Criticism on the Hermeneutical Method}

Critical methods arise based on the problems and difficulties of the form of texts, editorials, narratives, languages and literature contained in the Bible. Theology of Christian claims that Bible is the 'work' of some authors so it is regarded as the work of human beings. There is a difference between the authors which causes the Bible to be unlikely to say the word of God (harfiyah) literally and they almost agree that the Bible is harfiyah not the Kalam of God (16). Therefore, Christian theology needs hermeneutics to read the Bible 'between the line' to understand the true word of God.

The situation is different from the Muslim community because they can understand the revelation of Allah SWT from the Quran 'on the line' or 'between the line'. The Muslim community agrees that the Quran is Allah's message revealed to the Prophet and the Qur'an is a literally word of Allah. The Muslim community agreed to recite the Qur'an as a ritual and rewarded, reciting the Qur'an in prayer is a condition and understanding of the Qur'an as it is also permissible, while the translation of the Qur'an is not called as alQuran. Ibn 'Abbas once stated among the understanding of the Qur'an is a kind of interpretation that not everyone can understand it (la yaqdiru ahad fi fahmihi) (Ibn Kathir). This kind of understanding refers to the understanding of the harfiyah. Therefore, in Islam method interpretation Quran are differs from the Jews and Christians because they have no problem with the al-Quran itself.

\section{Methodology/Materials}

This paper seeks to explain the hermeneutical methods proposed by modern Islamic thinkers which are found to be contrary to the real concept of the Quran.

\subsection{Content Analysis}

In this article, the method used was qualitative method by using the content analysis method. Qualitative research is the process of finding information based on an understanding of data collection methods that are commonly used when reviewing a social problem (17). Through the method of content analysis, the method adopted is to describe objectively communication messages that have been printed, broadcasted or implied by hearing, acquiring and 
viewingthe text content either in words, pictures, symbols, ideas, themes, and any messages that have been communicated (18) Therefore, collecting data through content analysis can provide information that is relevant to the issues and problems that have been studied.

Content analysis conducted could gather relevant facts on hermeneutics methods that have been applied against the Quran by modern thinkers as well as collecting information in other forms of interpretation that have been conducted by these modern thinkers. The views of contemporary scholars onthe true interpretation of Quran was also identified to argue the opinions of the modern thinkers who justify the hermeneutics methods.

\subsection{Constant Comparison}

The information obtained through content analysis method were analysed using constant comparison method taken from arguments from the Quran and Hadith to obtain an accurate conclusion. With the methods used in this study, a conclusion that can be obtainedis hermeneutics interpretation is in contrary to the method prescribed by the mufassir, for this interpretation method is categorised in the mazmum tafsir which means obnoxious interpretation of Quran, and thus challenge againstthe modern Islamic thinkers' views.

\section{Results and Findings}

This study analysed the methods introduced by modern Muslim thinkers namely Fazlur Rahman, Nasr Hamid Abu Zayd and Arkoun who applying hermeneutics to the Quran. These scholars which were emphasizing hermeneutics aspects into meaning of revelation, interpretation etc.

\subsection{Interpretation Method by Fazlur Rahman}

Rahman (19) introduced a method in interpreting the Quran which is known as double movement. Measures taken to implement the methods are:

i. Finding the meaning of the Quranic text with a historical approach in a strict and truthful way. In the socio-historica context, the Quran must be studied within a chronological journey, beginning with an examination of the earliest revelations. This study will provide an accurate perception of the basic movements of the Islamic movement. This method can also save public from having an artificial interpretation (man made) done by the modernists though it clearly shows the overall meaning of the Quran.

ii. Distinguish specific legal provisions of the Quran with the Quranic moral ideal. Fazlur Rahman expects that the laws established could help him to devote himself to Him (God).

iii. Understand the purpose or morality ideal of the Quran to remain focused to sociology, which is the environment or the revelation of the Quran

According to Rahman (19), the method of interpretation that is acceptable and meets the demands of intellectual and moral integrity is a method that refers to its history, in a way that can purify the purposes of the Quran and Hadith. Thus, the double movement method can be done, not as the previous scholars who tend to exploit the legacy of classical Islamic history in addressing the issue of reform. For him, the past scholars were unsystematic in explaining the chronology of the Quran, so that sometimes the interpretations were repeated and did not result in a significant insight for life as a whole. This can be seen for example in explaining the interpretation of the Quran with the Quran ( القرآن (يفسر بعضه بعض does not include the integration of meanings of the systematic Quran in a complete world view. The method is said to be a double movement that can sum up this method of interpretation.

There are two movement sin the double movement method. First, the review focuses on the context of social studies and moral among people in the time of the Prophet, as well as providing a comprehensive description of the world at that time. Second, taking advantage of the general and systematic principles to be applied in the context of the present Quran readers. Furthermore, the method of applying a double movement has three levels, namely; the formulation of a worldview Quran, systematic ethical Quran and integrating ethics into contemporary context. The first method is the double movement, starting from the modern situation until the era of the Quran was revealed to be studied in order to understand the Quran that was sent down as a result of historical situation prevalent at that time. The second movement is from the time the Quran was revealed and back to the present time to connect the general teachings in the concrete socio-historical context in the present. Assessment should be done carefully so that the elements can be evaluated, modified and implemented as a priority in applying the Quran in reforms.

\subsection{Interpretation Method by Nasr Hamid Abu Zayd}

In criticizing the Quran, Abu Zayd (20) uses some methodology in presenting his ideas which include:

i. Review of Literature. Literary method is applied by Nasr in his criticism of the Quran. This is not something that is difficult for Nasr with his outstanding academic background in literature. For him, literature is one of the important methods to study and understand the text, which would give the correct facts to the understanding of Islam. Nasr's criticism about the Quran as cultural products is an evidence of literary criticism absorption that he has mastered. This is because Lucian Goldman assumed that literature is a product of history. Sociological literature on the other hand considers literary works as produced through meaningful contact which is the subject of the creator and the society $(21,22)$.

ii. Applying Hermeneutics. Hermeneutics is a scientific concept that dominated Nasr during his studies in the USA. For him with an applied hermeneutics, he gains more knowledge from time to time (4).

iii. The contextual interpretation of religious texts. This interpretation involves complementary mechanisms. First, ikhfa (concealment) and second, kashf (disclosure). Concealment is the original meaning of the text of the Quran, which revealed maghz $\bar{a}$, the significance or the final target Ikhfa' al-ma 'nain contrast is hiding the direct vicinity of the original meaning of the text. Second, kashf al-maghza also intends to unveil new meanings that are right which is referred as maghza (significance) (4).

iv. Distinguish the concept of interpretation and exegesis. Interpretation implies a return to the origins and to understand $m a ' n a$ and $m a g h z \bar{a}(4)$.

\subsection{Interpretation Method by Arkoun}

Interpretation method by Arkoun were involved following matters:

i. Analysis of language. The language aspect is important, as it is not to be a constant understanding, for the Quran will always be a discussion among those who are still alive. This can be found among the classic interpretations, where almost all of them tend to focus more on the language concept. Without understanding the language, interpretation would be "stiff" and the functions will be limited to textual only (23).

ii. Critic of History. Men from all centuries comprehend reality in certain ways. Therefore, they discuss in different ways as well. The way people talk is known as discourse. Arkoun divided history into three stages, namely; the classical era, the era of scholasticism and modern times. Arkoun did his research on the Quran and classical texts in order to find another hidden meaning of the context (23).

iii. Hermeneutics Applications. In carrying out the hermeneutic interpretation, Arkoun used the method of language thoughts circle of his time. This is because the whole interpretation 
would show the relationship between dimensions of language, thoughts and history. Arkoun also set several ways to produce such interpretations such as selecting the first text or forming text and hermeneutics text (23).

\subsection{Critique of Hermeneutics Method}

Criticism method appears based on the problems and difficulties of the text, editorial and narration, language and literature found in the Bible. In the Christians theology, to several authors, Bible is a 'work', thus it can be considered as the work of men. There are differences among the authors that resulted Bible would never be considered as literal Word of God and they almost agreed that Bible is not the Word of God (16). Therefore, the Christian theology needs hermeneutics to read the Bible 'between the lines' in order to understand the actual words of God.

The situation is different in the Muslim community because they can understand God's revelation of the Quran either the words are 'on the line' or 'between the lines'. The Muslim community agreed that Quran is the word of God revealed to the Prophet Muhammad and literally it is from God. This agreement also applies to the aspect of reading the Quran for harfiyah,it is a worship and will be rewarded, reading the Quran in prayers are obligatory and understanding the Quran for harfiyah is also allowed, while harfiyah translation and interpretation are not regarded as the Quran itself. Ibn Abbas has said that the understanding of Quran is a kind of interpretation not everyone can understand (la yaqdiru ahad fahmihi fi) (24). This kind of understanding refers to the literal understanding. Thus, the Muslim community is in contrast to Jews and Christians because they do not have a problem with the words in harfiyahin the Quran.

The idea that the Quran is 'a work inspired from the Divine' just like the Bible is clearly unacceptable to the Muslim community, because they do not consider the Quran as 'work' that require hermeneutics in understanding the work. The thought was actually came from those Orientalists who deceive Muslims to consider the Quran as the Prophet's work and Islam is a religion made by the Prophet Muhammad. Thus, the interpretation of the Quran in Islam is different from the hermeneutics method applied by the Christians in the Bible. The contemporary Muslim scholar, alAttas (25) clearly defines the difference between exegesis and hermeneutics. The difference is due to the scientific nature of the Arabic language structure, thus the first field of which the Muslims are capable ofis exegesis. This is not the same as Greek hermeneutics, not even like Christians hermeneutics, or even as 'hermeneutics' of other existing scriptures in their culture and civilization.

\section{Conclusion}

Based on the analysis performed, this modern thinkers have used the theories of hermeneutics as literary criticism, history and semiotic study of the Quran. The use of the method has downgraded the Quran by equating the Quran as literary works. Reinterpretationof the verses of the Quran based on the current context has made the issue of figh change and become controversial and this is against the opinion of the majority of scholars. This is because they use logic $\left(r a^{\prime} y\right)$ to interpret the law in the Quran. According to al-Khalidi, (26) tafsir bi al-ra'y (mazmum) is rejected because the interpretation of the Quran made is based on logic, desires, without dalil and can be considered as deviated from its true meaning. However, the idea of these people hailed by the Western society and their thoughtshave beenrecognized by the West and those who have the same thoughts with them.

Studies on modern Muslim thinkers and their work is an important study to determine the influence of their thoughts. Therefore, studies on the application of modern methods of interpretation of the Quran should be done to prevent the emergence of new relative interpretationswhich focus only to the current context and pose negative implications to the general public.

\section{Acknowledgement}

This work was supported in part by Vot U537 under Short Term Grant (STG) founded by Office For Research, Innovation, Commercialization and Consultancy Management (ORICC) University of Tun Hussein Onn Malaysia.

\section{References}

[1] Rippin A. Studying early" tafsir" texts. Der Islam; Zeitschrift für Geschichte und Kultur des Islamischen Orients. 1995;72:310.

[2] Esack F. Qurán, liberation and pluralism: An Islamic perspective of interreligious solidarity against oppression. 1997.

[3] Puji TIZT. Kritikan Islam liberal terhadap pentafsiran al-Qur'an: tumpuan kajian terhadap beberapa isu dalam'Ulum Al-Qur'an: Jabatan Al-Qur'an dan Al-Hadith, Akademi Pengajian Islam, Universiti Malaya; 2013

[4] Zainol NZN, Majid LA, Kadir MNA. Nasr Hamid Abu Zayd as a Modern Muslim Thinker. International Journal of Islamic Thought. 2014;5:61

[5] Rahman F. Islam: Past Influence and Present Challenge. Islam: Challenges and Opportunities. 1979:315-30.

[6] Schleiermacher F, Lücke F. On the Glaubenslehre: Scholars Press; 1981.

[7] Dilthey W. Introduction to the human sciences: Princeton University Press; 1991.

[8] Gadamer HG. Philosophische Lehrjahre E. Rückschau. 1977.

[9] Geiger A. One of the founders of the Reform movement in Germany. Glossary; 1810.

[10] Nöldeke T. The Iranian National Epic, or, The Shahnamah: Porcupine Press; 1930.

[11] Faiz F. Hermeneutika Qur'ani: antara teks, konteks, dan kontekstualisasi: melacak hermeneutika Tafsir Al-Manar dan Tafsir Al-Azhar: Qalam; 2002.

[12] Bauman Z. Hermeneutics and Social Science; Approaches to Understandinghutchinson 1978 .

[13] Husaini A. Yusril versus Masyumi: kritik terhadap pemikiran modernisme Islam Yusril Ihza Mahendra: Dea Press; 2000.

[14] Ibrahim M, Yaman A. Penyelewengan tafsir al-Qur'an: kritikan terhadap buku Fiqih lintas agama: Fakulti Pengajian Islam, Universiti Kebangsaan Malaysia; 2010.

[15] Palmer RE. Hermeneutics: Northwestern University Press; 1969.

[16] Imarah M, 'Imārah Muṣțafā 'Imārah M. Islam dan keamanan sosial: Gema Insani; 1999.

[17] Creswell JW, Plano Clark VL, Gutmann ML, Hanson WE. Advanced mixed methods research designs. Handbook of mixed methods in social and behavioral research. 2003;209:240.

[18] Babbie E. The practice of social research . Belmont, CA: Cengage Learning. Inc; 2010.

[19] Rahman F. Islam and modernity: Transformation of an intellectual tradition: University of Chicago Press; 1984.

[20] Abu Zayd NH. Dawair al-Khawf; Qira'ah fî Khitab al-Mar'ah. Beirut: al-Markaz al-Saqafi al-'Arabi. 1999.

[21] Rahman Y. THE HERMENEUTICAL THEORY OF NAȘR HAMID ABUZAYD: An Analytical Study of His Method of Interpreting the Qur'ān: McGill University Montreal, Canada; 2001.

[22] Fauzan A. Teks al-Qur'an dalam Pandangan Nashr Hamid Abu Zayd. Kalimah. 2015;13(1):71-92.

[23] Soekarba SR. Kritik Pemikiran Arab: Metode Dekonstruksi Mohammed Arkoun. Wacana. 2006;8(1):78-95.

[24] Ibn Kathīr I. Tafsīr al-Qur'ān al-'Azīm. Riyadh: Dar Taibah. 1999.

[25] Al-Attas SN. Konsep Pendidikan dalam Islam. Bandung: Mizan: 1999.

[26] al-Khalidi SA-F. Takrif al-Darisin bi Manahij al-Mufassirin. . Damsyik: Dar al-Qalam, 2010. 